\title{
THE SUITS IN ADMIRALTY ACT AND THE IMPLIED DISCRETIONARY FUNCTION
}

The Suits in Admiralty Act (SIAA) ${ }^{1}$ was enacted in 1920 as a narrow waiver of the Uinted States's sovereign immunity for admiralty claims arising from the use of government-owned ships as merchant vessels. ${ }^{2}$ In 1960 Congress amended the SIAA ${ }^{3}$ in an effort to resolve the nagging jurisdictional problem of the proper forum for a complaint that contains both admiralty and contract elements. ${ }^{4}$ This apparently innocuous amendment also attempted to eliminate confusion over the meaning of the terms "employed as a merchant vessel" and "public vessel,"s terms which respectively determined whether an action may be brought under the SIAA or its sister act, the Public Vessels Act (PVA). ${ }^{6}$ This latter change removed language restricting causes of action under the SIAA to damages caused by a government vessel einployed as a merchant vessel and inserted language that extended coverage of the SIAA to all admiralty causes of action that could be

1. 46 U.S.C. $\S \S 741-752$ (1976).

2. The relevant portion of the original Act provided:

That in cases where if such vessel were privately owned or operated, or if such cargo were privately owned and possessed, a proceeding in admiralty could be maintained at the time of the commencement of the action herein provided for, a hibel in personam may be brought against the United States or against such corporation [in which the Unitcd States or its representatives own all outstanding capital stock], as the case may be, provided that such vessel is einployed as a merchant vessel or is a tug boat operated by such corporation. Such suits shall be brought in the district court of the United States ...

Suits in Admiralty Act, Pub. L. No. 66-156, § 2, 41 Stat. 525-26 (1920) (current version at 46 U.S.C. \& 742 (1976)). (1958)).

3. See Act of Sept. 13, 1960, Pub. L. No. 86-770, § 3, 74 Stat. 912 (ainending 46 U.S.C. § 742

4. See notes 73-79 infra and accompanying text.

5. See notes 80-83 infra and acconpanying text.

6. 46 U.S.C. $\$ \$ 781-790$ (1976). Five years after the passage of the SIAA, which applicd only to ships employed as inerchant vessels, Congress enacted the PVA, an analogous statute dealing with claims for danage caused by public vessels, such as warships, Coast Guard vcssels, and other ships not involved im the merchant trade. The two statutes are similar but not identical. For example, there is a difference in venue and in interest-accrual provisions. Compare 46 U.S.C. $\S \S 742,743$ (I976) with id. $\S 782$. Additionally, the PVA includes some restrictions that are not a part of the SIAA, such as limitations on subpoenas directed to crew members of public vessels and reciprocity rcquirements for suits brought by foreign nationals. See id. $\$ \S 784-785$. To the extent the acts are not inconsistent, however, the SIAA and the PVA should be read in conjunction with one another. See United States v. United Continental Tuna Corp., 425 U.S. 164, 181 (1976); Calmar S.S. Corp. v. United States, 345 U.S. 446, 455 (1953); Blanco v. United States, 464 F. Supp. 927, 930 (S.D.N.Y. 1979); 46 U.S.C. § 782 (1976). 
brought against a private person or his property. ${ }^{7}$ The inajority of courts that have considered this change has concluded that the amendment drainatically expands the coverage of the SIAA to include all maritime torts, not just those involving inerchant vessels. ${ }^{8}$

As a result of the decisions allowing this broader coverage, the SIAA now enbraces in its admiralty jurisdiction tort claims against the government that previously could have been brought only under the Federal Tort Claims Act (FTCA). ${ }^{9}$ Additionally, because the FTCA specifically excludes claims cognizable under the SIAA and the PVA ${ }^{10}$, these two statutes are now the exclusive vehicles for bringing such tort suits. Confusion has returned, however, as courts atteinpt to outline the limits of the government's waiver of sovereign immunity for those maritime torts formerly covered by the FTCA that are now covered by the SIAA. Specifically, neither the SIAA nor the PVA contain an exphicit exeinption froin the waiver of sovereign immunity for discretionary functions-generally, those governmental decisions involving sonie degree of pohicy inaking ${ }^{11}$ nade by nonjudicial officials-as does the FTCA. ${ }^{12}$ This comment considers the question of whether the SIAA contains an imphed discretionary-function exeinption and concludes that it does.

This conclusion is supported by the doctrine of separation of powers and the legislative history of the SIAA, the PVA, and the 1960 amendments to the SIAA. The separation of powers doctrine recog-

7. The amended statute reads:

In cases where if such vessel were privately owned or operated, or if such cargo were privately owned or possessed, or if a private person or property were involved, a proceeding in admiralty could be maintained, any appropriate nonjury proceeding in personam may be brought against the United States.... .

46 U.S.C. $\$ 742$ (1976).

8. See cases cited in note 88 infra.

9. Legislative Reorganization Act of 1946, Pub. L. No. 79-601, tit. iv, 60 Stat. 812, 842 (codified in scattered sections of $28,31,33$ U.S.C.).

10. 28 U.S.C. $\$ 2680$ (d). This section provides that the FTCA does not apply to "[a]ny claim for which a remedy is provided by sections $741-752,781-790$ of Title 46 , relating to claims or suits in admiralty against the United States." Id. See also 46 U.S.C. \& 740 (1976) (a similar provision for exclusive handling of admiralty claims under the SIAA or the PVA).

11. For a discussion of the ineaning of the discretionary-function exemption in the FTCA, see 3 K. Davis, Administratrive Law Treatise $§ 25.08-.13$ (1958 \& Supp. 1970); Matthews, Federal Tort Claims Act-The Proper Scope of the Discretionary Function Exception, 6 AM. U.L. REv. 22 (1957); Reynolds, The Discretionary Function Exception of the Federal Tort Claims Act, 57 GEo. L.J. 81 (1968); Zillman, The Changing Meanings of Discretion: Evolution in the Federal Tort Claims Act, 76 Mil. L. Rev. 1 (1977). See generally L. JAYSON, HANDLING FEDERAL TORT Claims: Administrative and Judicial Remedies (2d ed. 1974 \& Supp. 1981).

12. Compare 46 U.S.C. $\S \S 742,746,781,787$ (1976) with 28 U.S.C. $\$ 2680$ (1976). For the text of the discretionary-function exemption in the FTCA, see text accompanying note 104 infra. 
nizes the limits of judicial power to review the discretionary ${ }^{13}$ decisions of a coordinate branch of government absent congressional authorization. The legislative history of the acts and the anendments reveal a dearth of inaterial concerning Congress's intent in broadening the coverage of the SIAA in the 1960 ainendments. There was no clear recognition that the amendment would substantially affect the handling of inaritime tort claims. ${ }^{14}$ It is appropriate, therefore, to treat such claims as they were treated under the FTCA, before the 1960 SIAA amendments. ${ }^{15}$

\section{The DifFering Judicial Conclustons Concerning the IMPLIED DISCRETIONARY-FUNCTION EXEMPTION}

Under the generally accepted view of sovereign immunity, the United States may not be sued absent its consent. ${ }^{16}$ Consent is ordinarily achieved through statutes waiving immunity for certain actions. ${ }^{17}$ When presented with a broad waiver of immunity, ${ }^{18}$ courts necessarily

13. For the purposes of this comment it is assumed that the discretionary-function exemption refers to decisions that are primarily policy-making, such as decisions implementing programs or setting priorities for determining the proper allocation of an agency's resources. See note 11 supra and accompanying text and text accompanying notes 122-25 infra.

14. See notes 73-88 infra and accompanying text.

15. See notes $101-125$ infra and accompanying text. There are three ways to analyze whether an implied discretionary-function exemption exists in the SIAA. The first approach reasons that because no restrictions on the waiver of sovereign immunity appear on the face of the statute, the statute slould be taken as a complete waiver of immunity. See notes 19-24 infra and accompanying text. The second approach includes in the analysis a consideration of the legislative history and the separation of powers doctrine, factors that support inferring a discretionary-function exeinption into the SIAA. See notes 25-36 infra and accompanying text. The third method narrowly construes the revised SIAA, confining the Act to its pre-1960 role of resolving shipping claims. This imterpretation, recently advanced in McConmick v. United States, 645 F.2d 299 (5th Cir. 1981), focuses primarily on the legislative history of the 1960 SIAA amendments and the Supreme Court's interpretation of that history in United States v. United Continental Tuna Corp., 425 U.S. 164 (1976). Under this approach nonshipping-maritime torts are still covered by the FTCA. 645 F.2d at 303-07, 309-10. This analysis eliminates the need to decide whether the SIAA contains an implied discretionary-function exemption for maritime torts previously covered by the FTCA.

This comment focuses on the first two approaches. It does so for two reasons. First, the predominant view of the courts is that the 1960 amendments did expand the coverage of the Act to include all inaritime torts. Second, the McCormick approach parallels the second approach mentioned above in its emphasis on the legislative history and, by recognizing FTCA coverage of nonshipping maritime torts, lias the same practical effect of affording the discretionary-function protection to the government.

16. E.g., United States v. Mitchell, 445 U.S. 535, 538 (1980); United States v. Sherwood, 312 U.S. 584, 586-87 (1941); United States v. Slıaw, 309 U.S. 495, 500-01 (1940).

17. See, e.g., United States v. Mitchell, 445 U.S. 535, 538 (1980); Affiliated Ute Citizens v. Umited States, 406 U.S. 128, 141-43 (1972); United States v. Shaw, 309 U.S. 495,503 (1940); Munro v. United States, 303 U.S. 36, 41 (1938).

18. An example of broad wording is the "private person or property" language in the SIAA, 46 U.S.C. $\$ 742$ (1976). See note 3 supra. 
have considerable latitude in defining the precise limits of the waiver. The decisions interpreting the scope of the waiver of immunity in the SIAA illustrate the variation that results.

In Lane v. United States ${ }^{19}$ a inotorboat owner who had struck an unmarked, sunken barge alleged that the Coast Guard was neghigent in failing to inark the barge. The Court of Appeals for the Fourth Circuit took a direct approach in concluding that there was no imphed discretionary-function exeinption in the SIAA. The court simply noted that the language of the SIAA differs from that of the FTCA in that the SLAA contains no exphicit exceptions to the waiver of sovereign immunity. Hence, the court reasoned that there is "no basis" for importing the exceptions of the FTCA into the SIAA.20 The Lane opinion offers no extensive analysis of the SIAA or of waivers of sovereign immunity in general. It does demonstrate, however, one approach to interpretimg statutes waiving sovereign immunity: the waiver is given the broadest interpretation consistent with the language of the statute. ${ }^{21}$

A similar expansive reading of statutory waivers of immunity is evident in DeBardeleben Marine Corp. v. United States. ${ }^{22}$ Although the DeBardeleben court did not decide the specific question of whether the SIAA contained an implied discretionary-function exemption, ${ }^{23}$ it

19. 529 F.2d 175 (4th Cir. 1975).

20. Id. at 179.

21. Although irrelevant to its interpretation of the SIAA, the court determined that under the Wreck Act, 14 U.S.C. $\$ 86$ (1976), the Coast Guard's decisions about marking sunken wrecks were discretionary but that such discretion inust be exercised responsibly. 529 F.2d at 179. The court concluded: "[The Coast Guard] is not to ignore subinerged wrecks of which [they are] informed, or fail to mark them if they constitute real dangers to navigation." Id. at 179. The court's zeal in interpreting this supposedly discretionary duty may be due in part to proof that eight to ten pleasure boats a year had run up on the wreck for each of the five years the wrcck had been unmarked. See id. at 177. It is interesting to compare this view of discretion with the discretionary-function exemption in the FTCA, which states specifically that the exeinption applies "whether or not the discretion involved be abused." 28 U.S.C. \$ 2680(a) (1976).

The problem with adopting a strict standard of review of the exercise of discretion, as the Lane court advocates, is that the immunity becomes illusory. Justice Rehnquist cogently articulated this dilemma in Butz v. Econonou, 438 U.S. 478 (1978). That case involved the scope of a government official's immunity from suit for a constitutional tort. The majority held that the Secretary of Agriculture has only a qualified immunity froin suit for a constitutional wrong. Justice Rehnquist, in a dissenting opinion, noted: "[The majority's opinion] amounts to saying that an official has immunity until someone alleges that he acted unconstitutionally. But that is no immunity at all: The 'immunity' disappears at the very moment it is needed." Id. at 520 .

22. 451 F.2d 140 (5th Cir. 1971).

23. In DeBardeleben the court had to decide the analogous question of whether to incorporate another of the FTCA's specific exemptions-that for the tort of misrepresentation-into the SIAA. Tugboat and barge owners, whose vossels were damaged when a natural gas pipeline ruptured and exploded after an anchor had caught on it, claimed that the government was guilty of misrepresentation in supplying an inproperly updated chart that did not reflect the presence of the pipeline. Id. at 141-42. The court refused to imply any of the FTCA's exemptions into the 
stated that because the historical trend is away from sovereign immumity, "[a]ny doubts as to its waiver . . . are to be resolved agaimst the sovereign." 24

A different judicial disposition toward the interpretation of immumity statutes is present in Gercey v. United States. ${ }^{25}$ In Gercey the Court of Appeals for the First Circuit held that there is an implied discretionary-function exemption in the SIAA, reasoning that courts should be circumspect about reviewing adimimistrative and legislative policy decisions absent specific authorization from Congress. ${ }^{26}$ The court concluded that if the judiciary becomes too embroiled in policy decisions concerning the use of limited resources for the public imterest, an "intolerable state of affairs" would result.27 A close reading of the court's opimion reveals a deference to the doctrine of separation of powers; specifically, a respect for the policy decisions properly made by the other branches of government. The court confined its deference, however, to those policy judgments affecting the public interest. ${ }^{28}$

SIAA. Id. at 145-46. Even though the court rejected most of the government's legal arguments, the government still won the case because the government owed no duty to the users of the old chart after it had issued two notices that stated that a new, up-to-date chart had been issued.

24. Id at 143. In a footnote, the court sought to support its argument by noting that the discretionary-function exemption also should not be imported into the SIAA. It reasoned that the government's operation of a warship is purely discretionary and that the government has accepted hability in cases arising from damage caused by its warships. Id. at 146 n.15.

Two observations on this point are in order. First, the court was referring to the waiver of immurity in the PVA, not the SIAA, although it did not acknowledge that fact. Second, this rationale assumes that any operation of a warship is a discretionary act. This assumption defines discretion so broadly that it would include every decision unade at any level by a government employee; generally, this definition has not been accepted. See note 11 supra. See Gercey v. United States, 540 F.2d 536, 539 n.4 (1st Cir. 1976), cert. denied, 430 U.S. 954 (1977) (the operation of a ship "does not involve a basic policy judgment of how best to promote the public interest and, as such, is not a 'discretionary function' ").

Although the court's subsequent decision in McCormick v. United States, 645 F.2d 299 (5th Cir. 1981), rejected DeBardeleben's conclusion that the SIAA embraces all maritine torts, id. at 309, McCormick reaffirmed DeBardeleben's reasoning concerning sovereign immunity. Id. at 309 n.18.

25. 540 F.2d 536 (1st Cir. 1976), cert. denied, 430 U.S. 954 (1977). In Gercey the claims arose when a charter-fishing boat sank, drowning several passengers. The Coast Guard had earlier revoked the boat's certification to carry passengers after an inspection revealed the decayed condition of the boat's lull. The owner of the boat at the time of the revocation sold it to another operator, who started clarter operations. The parents of one of the deceased passengets alleged that the Coast Guard had been negligent in failing to ensure that the boat was not used to carry commercial passengers. $540 \mathrm{~F} .2 \mathrm{~d}$ at 537.

26. Id. at 539.

27. Id. The Gercey court concluded that the question of whether the Coast Guard should impleinent a follow-up program for decertified vessels was a discretionary matter involving a policy decision about how to use limited resources to best promote the public interest.

28. Id. See also Boston Edison Co. v. Great Lakes Dredge \& Dock Co., 423 F.2d 891, 896-97 (1st Cir. 1970) (the court implicitly acknowledged the presence of a discretionary-function exemption in the SIAA for similar reasons). 
Basing its decision largely on the doctrine of separation of powers, the Court of Appeals for the District of Columbia Circuit found an implied discretionary-function exemption in the SIAA in Canadian Transport Co. v. United States. ${ }^{29}$ The court viewed the implied exemption not as "an atteinpt to rewrite the statute, but merely [as] an acknowledgement of the limits of judicial power." 30 Additionally, the court noted that the legislative history of the 1960 amendments to the SIAA did not support a substantive clrange in the waiver of sovereign immumity for maritime torts. ${ }^{31}$

The limited scope of the 1960 amendments was an important part of the Court of Appeals for the Seventh Circuit's analysis in Bearce $v$. United States. ${ }^{32}$ The court quoted at length from Gercey ${ }^{33}$ and found further support for a narrow reading of the 1960 amendinents in the Supreme Court's 1976 decision im United States $v$. United Continental Tuna Corp. ${ }^{34}$ whicl held that the 1960 amendinents to the SIAA do not alter the jurisdictional requirements of the PVA. ${ }^{35}$ On these bases, the court held that the SIAA contains an implied discretionary-function exemption. ${ }^{36}$

29. 1980 A.M.C. 2103 (D.C. Cir. 1980). In this case the shipping company alleged that the Coast Guard had intentionally interfered with its contract rights by invoking provisions of the seldom used Special Interest Vessel program to prohibit a freighter froun entering Norfolk harbor, an area with numerous naval facilities, until the Polish crew of the ship had been replaced by crew members from noncommunist countries. Id. at 2105-06. The district court opinion is discussed extensively in Canadian Transport Company v. United States: An Avenue Toward a Remedy for a Treaty Violation, 9 CAL. W. INT'L L.J. 377 (1979).

30. 1980 A.M.C. at 2110. The court in Canadian Transport also concluded that the planning/operational standard is the appropriate means to analyze whether an act or decision is covered by the discretionary-function exemption. Id. at 2110-11. For further discussion of the planning/operational standard, see notes 117-125 infra and accoinpanying text.

31. 1980 A.M.C. at 2108-09. For further discussion of the legislative history of the SIAA, see notes 53-88 infra and accompanying text.

32. 614 F.2d 556 (7th Cir.), cert. denied, 449 U.S. 837 (1980). Bearce was a wrongful death action arising froun a boating accident on Lake Michigan. The Coast Guard was allegedly neghgent in its failure to light both ends of a breakwater that marked a seldoin used entrance to Chicago harbor. 614 F.2d at 557-58.

33. Id. at 559 (quoting Gercey v. Umited States, 540 F.2d 536, 539 (1st Cir. 1976), cert. denied, 430 U.S. 954 (1977)). Included in the material quoted was the Gercey court's consideration of the public policy reasons for inferring the discretionary-function exemption. See notes 25-28 supra and accompanying text.

34. 425 U.S. 164 (1976).

35. For a discussion of the facts and lolding of United Continental Tuna, see notes 89-96 infra and accompanying text.

36. 614 F.2d at 560. In Rappenecker v. United States, 509 F. Supp. 1024 (N.D. Cal. 1980), the court adopted the reasoning of the Bearce and Gercey decisions in deciding to imply a discretionary-function exemption into the SIAA. In Rappenecker the court leld that the military rescue mission to recapture the S.S. Mayaguez, after Cambodian forces had illegally seized it in international waters, involved a basic policy judgment concerning the national interest and thus fell 
Finally, in Magno v. Corros $^{37}$ the Court of Appeals for the Fourth Circuit reversed a lower court decision ${ }^{38}$ that had held the United States liable for a portion of the damage sustained in a notorboat's collision with a dike. ${ }^{39}$ The court distinguished Lane $v$. United States, ${ }^{40}$ but did not specifically address the discretionary-function issue. The court recognized the budgetary impact of holding the Coast Guard liable in cases that involve discretion in the placement of the navigation aids. The court reasoned that absent a congressional mandate requiring additional navigational aids "it is usually inappropriate for a federal court to impose such a requirement and in effect direct the Coast Guard how to spend its limited resources." 41 The court appeared to be reconsidering the strict standards of Lane, ${ }^{42}$ expressing concern over judicial control of the limited resources of an executive agency. This concern is similar to the discretionary-function concept; both reflect deferral to policy decisions concerning the allocation of resources.

Courts that have examined whether there is an implied discretionary-function exemption in the SIAA ${ }^{43}$ have collcctively identified the

within the discretionary-function exemption. The personal injury actions brought by former Mayaguez crewmen, therefore, were not actionable under the SIAA. Id. at 1026-28.

37. 630 F.2d 224 (4th Cir. 1980), cert. denied, 451 U.S. 970 (1981).

38. Magno v. Corros, 439 F. Supp. 592, (D.S.C. 1977), rev'd, 630 F.2d 224 (4th Cir. 1980), cert. denied, 451 U.S. 970 (1981).

39. The Court of Appeals for the Fourth Circuit found no evidence that the lack of lighting on the dike induced the boater to believe that the dike was not in his path. Additionally, the court noted that the government had not undertaken to light the entire length of the dike; thus, it could not be held liable on a "Good Samaritan" theory, as it had been in Indian Towing Co. v. United States, 350 U.S. 61 (1955). 630 F.2d at 228-29. In Indian Towing the Coast Guard was held liable for damages sustained by a barge owner whose vessel grounded because of an moperative hight in a navigation aid. The government conceded that mamtenance of the hight was not discretionary and instead argued that there was no analogous private liability for failing to inaintain navigation aids, hence the FTCA did not reach such activity. 350 U.S. at 64-66. Rejecting the government's argiment, the Court held that once the Coast Guard had undertaken to warn mariners of navigational hazards, it had to continue to do so in a careful manner, and that allowing the inoperative light in the navigation aid to go unrepaired was neghigence actionable under the FTCA. Id. at 69.

40. 529 F.2d 175 (4th Cir. 1975). The Magno court distinguished Lane on two grounds. First, the court noted there was no duty to mark the dike in the first instance, for the dike was a congressionally authorized aid to navigation and did not fall under 14 U.S.C. $\$ 86$ (1976), which the Lane court had relied upon and whieh provides the Coast Guard with the authority to mark sunken vessels or other obstructions to navigation. Second, the court found no analogous private liability for failure to inark a dike, which supported its position that there was no duty to mark the dike in the first place. $630 \mathrm{~F} .2 \mathrm{~d}$ at $227-28$.

41. 630 F.2d at 229.

42. See notes 19-21 supra and accompanying text.

43. In addition to the decisions previously discussed, several lower courts have also mentioned the issue. These courts, however, have not offered any new analysis of the topic; rather, they merely cite to an opinion of that circuit's court of appeals and state their views in a conclusory fashion. See, e.g., Offshore Transp. Corp. v. United States, 465 F. Supp. 976, 981 (E.D. La. 1979); Doyle v. United States, 441 F. Supp. 701, 709 (D.S.C. 1977); Hogge v. S.S. Yorkmar, 
principal considerations as: the statute's plain language, which contains no specific exemptions to the waiver of sovereign immunity; the doctrine of separation of powers, which fosters a judicial reluctance to review policy decisions made by coordinate branclies of government; and the legislative histories of the SIAA and the 1960 ainendinents, which lack any indication that Congress desired a substantive cliange in government liability for maritime torts. The legislative history and judicial construction of the SIAA, the PVA, and the discretionary-function exemption of the FTCA are useful in analyzing these concerns and in deciding whether the SIAA contaims a discretionary-function exemption.

\section{Legislative History and Judicial Development}

\section{A. The SIAA and the PVA.}

The SIAA was enacted to alleviate the problems caused by the federal government's operation of large numbers of mercliant ships during and after World War I. Prior to World War I, the government was not significantly involved in mercliant shipping activities. Consequently, private individuals rarely needed relief for damages caused by government vessels. ${ }^{44}$ When such occasions did arise, Congress resolved the disputes through private relief bills. ${ }^{45}$ The advent of World War I dramatically changed this situation. Because Gerunan submarines were exacting a high toll on commercial shipping, the government became extremely active in the construction and operation of merchant vessels. One result of the government's increased activity was an increased number of claims agamst the government for damages caused by government vessels. ${ }^{46}$

In the Shipping Act of $1916^{47}$ Congress provided for the first waiver of sovereign immumity ${ }^{48}$ covering government merchant vessels

434 F. Supp. 715, 732 n.3 (D. Md. 1977). But see Rappenecker v. United States, 509 F. Supp. 1024, 1026-28 (N.D. Cal. 1980), discussed in note 36 supra.

44. See Note, The Maritime Liability of the United States, 100 U. PA. L. Rev. 689, 691 (1952).

45. $I d$.

46. Id.

47. Pub. L. No. 64-260, 39 Stat. 728 (current version at 46 U.S.C. $\S 808$ (1976)).

48. The relevant portion of the statute read as follows:

That any vessel purchased, chartered, or leased from the board may be registered or enrolled and licensed. . . , as a vessel of the United States and entitled to the benefits and privileges appertaining thereto: Provided, That ... [s]uch vessels while employed solely as merchant vessels shall be subject to all laws, regulations and liabilities governing merchant vessels, whether the United States be interested therein as owner in whole or in part, or liold any mortgage, lien, or other interest therein.

Id. at $\$ 9,39$ Stat. at 730 . The Act also provided for government shipbuilding programs and the establishment of a government corporation to operate merchant ships. 
operated by the United States Shipping Board Einergency Fleet Corporation. ${ }^{49}$ The Supreme Court, in The Lake Monroe, ${ }^{50}$ construed the statute to be a complete waiver of immunity. 51 Thus, governmentowned ships were subject to the traditional admiralty law reinedies of arrest and in ron1 proceedings. 52

Congress disagreed with the results of the Lake Monroe holding. ${ }^{53}$ The problem of seizures of government vessels for in rem proceedings had reached epidemic proportions ${ }^{54}$ and was subjecting the United States "to unnecessary expense and its vessels to great delays." 55 To rectify this situation, Congress passed the SIAA in 1920.56

The SIAA was narrowly drawn to reach only those ships entployed as merchant vessels. It provided that only libel in personam actions could be brought. 57 Congress decided that the rcmoval of the in rein right to seize government vessels, which arose after the Lake Monroe decision, would alleviate thc einbarrassnicnt, time, and expense to the government resulting frond the detention of its ships, without seriously impairing claimants' remedies because the United States was "absolutely responsible" for its dcbts and could be relied on to pay

49. The Federal Maritime Commission is the modern day successor of the Emergency Fleet Corporation.

50. 250 U.S. 246 (1919).

51. The Lake Monroe, a government owned vessel operated by a private company acting as an agent for the Emergency Fleet Corporation, collided with a private vessel off the coast of Cape Cod. The Supreme Court upheld the district court's interpretation of section 9 of the Shipping Act, which provided that the United States was entitled to all the benefits and privileges of a private owner, and held that the United States was to be subject to the same liabilities as private individuals. Following this rationale, the Court noted that government vessels could be seized and put in the court's custody under traditional admiralty in rem proceedings. Id. at 248, 254-56.

52. Admiralty law provides for both in personam proceedings to impose personal liability on a corporate or natural person and for in rem proceedings. The former proceedings are predicated on the existence of a maritime lien, which arises if, for example, a ship causes damage to another vessel or to shore fixtures. Under im rem proceedings the court arrests the vessel and lolds it for sale to satisfy the maritime liens against it, and the owner can recover control of the vessel only by posting a bond. G. GilmORE \& C. BLACK, THE LAW OF ADMIRALTY 34-37 (2d ed. 1975).

53. See H.R. Rep. No. 497, 66th Cong., 2d Sess. 3 (1919).

54. See id. The report stated: "Almost daily such seizures occur, and under existing law there is no speedy remedy for their release." $I d$.

55. S. Rep. No. 223, 66th Cong., 1st Sess. 3 (1919).

56. Pub. L. No. 66-156, 41 Stat. 525 (1920) (current version at 46 U.S.C. $\$ 8741-752$ (1976)).

57. Pub. L. No. 66-156, 41 Stat. 525, 526 (1920). The act provided:

[I]n cases where if such vessel were privately owned or operated, or if such Cargo were privately owned and possessed, a proceeding in admiralty could be maintained ...., a bibel in personam may be brought against the United States or against such corporation, as the case may be, provided that such vessel is employed as a merchant vessel or is a tug boat operated by such corporation.

Id. at $525-26$. 
any judgment rendered against it. 58 The congressional intent in passing the SIAA is succinctly stated in the House Report on the bill: "The object of this bill is not to add to the liability of the Government, but to prevent the seizure and detention of our ships, so as to eliminate this unnecessary loss." 59

Congress did not address in the SIAA the question of claims for damages caused by public vessels. ${ }^{60}$ An attempt to include a provision addressing this problem failed because legislators considered such an expansion of the government's hability too drastic to be included in what was considered an emergency bill to solve a narrow problem. ${ }^{61}$ Failure to provide for the problein of damages caused by public vessels led to a stream of private relief bills for such damages, ${ }^{62}$ and in 1925 Congress responded by enacting the PVA. ${ }^{63}$ The House Report ${ }^{64}$ specified that the main purpose of the PVA was to allow submission of admiralty claims to the courts, eliminating the need for Congress to spend time and energy on private rehef bills, thereby achieving faster and more effective resolution of the claims. ${ }^{65}$

The House Report on the PVA discussed the general question of sovereign immunity, reviewing the progressively more extensive waivers made by Congress since the founding of the Republic. ${ }^{66}$ The historical movement, the report noted, was toward greater equality between the state and the individual before the law. 67 This perspective is tempered, however, by the report's discussion of Walton $v$. United States, ${ }^{68}$ an 1889 Court of Claims case discussing the proper scope of sovereign immunity, which is cited as support for the waiver of immunity in the PVA. The Walton court noted that the government's immunity should not extend to situations in which it engages in an enterprise for profit or

58. S. REP. No. 223, supra note 55, at 3 . One of the reasons for the development im admiralty law of the maritime lien and in rem proceedings was to ensure that the court liad control of property that could be used to pay a judgment. See G. Gilmore \& C. BlaCx, supra note 52, at 35-36.

59. H.R. REP. No. 497, supra note 53, at 3.

60. For a discussion of the meaning of the term "public vessels," see note 6 stupra.

61. The House Report commented: "[T]o authorize suits against the United States for damages occasioned by any public vessel ... would involve a [r]adical change in the policy this Government has heretofore pursued . . ." H.R. ReP. No. 497, supra note 53, at 4.

62. See H.R. Rep. No. 913, 68th Cong., 1st Sess. 1 (1924).

63. Pub. L. No. 68-546, 43 Stat. 1112 (1925) (current version at 46 U.S.C. $\$ \S 781-790$ (1976)).

64. H.R. REP. No. 913, supra note 62.

65. Id. at 1-2. The Act provides that a "libel in personam in admiralty may be brought against the United States . . . for damages caused by a public vessel of the United States." Pub. L. No. 68-546, 43 Stat. 1112 (1925) (current version at 46 U.S.C. $\$ 781$ (1976)).

66. H.R. REP. No. 913, supra note 62, at 4-6.

67. Id. at 3-4.

68. $24 \mathrm{Ct}$. Cl. 372 (1889). 
to situations in which it operates its property on equal terms with the general citizenry. ${ }^{69}$ The latter situation includes the operation of vessels in navigable waters. An important caveat, however, to this view supporting the waiver of immunity is that the government, according to the Walton court, should not be liable " for loss or dainage occasioned to private citizens by reason of any imperfection in the performance of the ordinary functions of Government, or by reason of the acts, omissions, or negligence of its officers or agents in the discliarge of sucls functions." "70 This statement reflects Congress's perception of the waivers of immunity in both the SIAA and the PVA ${ }^{71}$ as waivers that are directed at specific probleins involving ships operating in navigable waters ${ }^{72}$ and its perception that such waivers are not intended to reach broader governmental decisions.

\section{B. The History of the 1960 Amendments to the SIAA.}

The SIAA reinained in its original form, with minor modifications, ${ }^{73}$ until 1960. The primary intent behind the 1960 aunendinents was to solve jurisdictional problems between the SIAA and the Tucker Act. ${ }^{74}$ The Tucker Act provided for exclusive jurisdiction in the Court

69. Id. at 379 (quoting from an unidentified Senate Report), cited with approval in H.R. REP. No. 913, supra note 62, at 3 . In Walton Congress had passed a special bill authorizing the Court of Claims to take jurisdiction over the claims of an owner of a river steamer and barges whose vessels had sunk following a collision with unlit government piers on the Ohio River. The court relied on the congressional reports in interpreting the scope of the waiver of immunity in the bill giving the court jurisdiction of the case. $24 \mathrm{Ct}$. Cl. at 377-80.

70. 24 Ct. Cl. at 379, quoted with approval in H.R. REP. No. 913, supra note 62, at 3.

71. See H.R. ReP. No. 913, supra note 62, at 3; S. REP. No. 223, supra note 55, at 3; H.R. REP. No. 497, supra note 53, at 1-3.

72. Before the 1960 amendments, the significant cases interpreting the SIAA and the PVA dealt with the handling of vessels and their cargoes. For example, the PVA's coverage of noncollision damage was the subject of debate until 1945 when the Supreme Court rendered its decision in Canadian Aviator, Ltd. v. United States, 324 U.S. 215 (1945). The case arose after a merchant ship was ordered to follow a stuall naval vessel into the Delaware Bay. The naval vessel led the merchant ship over a subinerged wreck, damaging the merchant ship. Because there had been no collision between the naval vessel and the merchant ship, the government argued that the suit was outside the purview of the PVA. The Court held that although the bill had originally been limited to collision damage, Congress had consciously changed the statute's wording before its enactment; hence, the PVA imcluded actions for damages from publie vessels even if there was no collision. Id. at 224-25. See also American Stevedores v. Porello, 330 U.S. 446 (1947) (holding the PVA makes the government hable for personal injuries sustamed on a public vessel).

73. See, e.g., Act of Dec. 13, 1950, Pub. L. No. 81-877, 64 Stat. 1112 (amendimg 46 U.S.C. $\$ 745$ (1950)) (extending the time limit in which to bring certain actions); Act of June 30, 1932, Pub. L. No. 72-213, 47 Stat. 420 (providing a saving clause for those who had claims pending in other courts when the Supreme Court decided in Johnson v. United States Shipping Bd. Energency Fleet Corp., 280 U.S. 320 (1930), that the SIAA provides the exclusive renedy for claims against the Emergency Shipping Board).

74. See note 86 infra and accompanying text. 
of Claims for contract claims against the government in excess of $\$ 10,000.75$ The SIAA and the PVA provided that federal district courts had exclusive jurisdiction over any claim against the United States sounding in admiralty. ${ }^{76}$ This situation posed a dilemma for the individual with a contract claim exceeding $\$ 10,000$ that was based on sone type of maritime transaction, for a suit filed in the wrong court could not be transferred to the proper forum; rather, it had to be dismissed and re-filed.77 Additionally, the commencenient of an action under one statute did not toll the statute of limitations of the other statute. Considering the SIAA's two-year statute of limitations, ${ }^{78}$ it was conceivable that an action originally brought under the Tucker Act ${ }^{79}$ that was deemed to involve an admiralty question would be dismissed by the Court of Claims although it was time barred in the district court.

Adding to this confusion was the uncertainty over classifying vessels as "employed as a merchant vessel" or employed as a "public vessel." This classification determined whether an action could be brought under the SIAA or the PVA. Additionally, because a vessel conceivably could not be "employed as a merchant vessel" and still escape classification as a "public vessel," 80 all contract claims involving such a vessel came under the purview of the Tucker Act, ${ }^{81}$ and all tort claims were covered by the FTCA. This confusion frequently caused lawyers to proceed under an incorrect statute in an improper forum, ${ }^{82}$

75. See 28 U.S.C. $\$ \S 1346(a)(2), 1491$ (Supp. III 1979).

76. See 46 U.S.C. $\$ \S 742,782$ (1958) ( $\$ 742$ amended 1960).

77. See S. Rep. No. 1894, 86th Cong., 2d Sess. 3 (1960), reprinted in [1960] U.S. CoDE CoNG. \& AD. NEws 3583, 3584. A suit could not be filed simultaneously in the district court and in the Court of Claims because the latter court had no jurisdiction of a claim pending in another court. See 28 U.S.C. \& 1500 (1976).

78. 46 U.S.C. $\$ 745$ (1976).

79. The Tucker Act has a six-year statute of limitations. 28 U.S.C. $\$ 2401$ (a) (1976).

80. The confusion is illustrated in Calmar S.S. Corp. v. U1rited States, 103 F. Supp. 243 (S.D.N.Y. 1951), rev'd sub nom., Calmar S.S. Corp. v. Scott, 197 F.2d 795 (2d Cir. 1952), vacated sub nom, Calmar S.S. Corp. v. United States, 345 U.S. 446 (1953). In Calmar the government chartered a private merchant ship to transport war supplies. Enemy aircraft sank the ship. The district court took jurisdiction under the SIAA, implying that the PVA was inapplicable because the ship was privately owned and operated. 103 F. Supp. at 262-63. The Court of Appeals for the Second Circuit reversed, holding that because the ship was carrying war nuterial it was not "employed as a merchant vessel." 197 F.2d at 801 . The Supreme Court held that the nature of the cargo was irrelevant and that the claim was properly considered under the SIAA. 345 U.S. at 447, 455-56.

81. Claims for amounts exceeding $\$ 10,000$ came under the exclusive jurisdiction of the Court of Claims. 28 U.S.C. $\S \S 1346$ (a)(2), 1491 (Supp. III 1979).

82. See S. REp. No. 1894, 86th Cong., 2d Sess. 3 (1960), reprinted in [1960] U.S. CODE CONG. \& AD. NEWS $3583,3584$. 
with potentially disastrous effects resulting from the different statutes of limitations. ${ }^{83}$

The solution to these problems was twofold. First, Congress gave the Court of Claims and district courts authority to transfer cases to one another if a case exclusively within the jurisdiction of one court was filed in the wrong court, but only if it was in the "interest of justice" to do so. ${ }^{84}$ Second, the SIAA was amended so that the phrase "or if a private person or property were involved" was substituted for the original, more restrictive clause, "provided that such vessel is employed as a merchant vessel or as a tugboat operated by such corporation." 85 There is hittle legislative history concerning the latter change, but the naterial that does exist indicates that this alteration also was made to clarify the scope of the admiralty jurisdiction of the district courts. ${ }^{86}$

83. See note 79 supra and accoinpanying text.

84. See 28 U.S.C. $\$ \S 1406$ (c), 1506 (1976). The phrase "in the interest of justice" was added on the advice of the Secretary of Commerce to give courts the discretion to dismiss cases with prejudice if it appeared the case had been purposely filed in the wrong court in bad faith. See $\mathbf{S}$. REP. No. 1894, supra note 82, at 9-10, reprinted in [1960] U.S. Code CoNG. \& AD. NEws 3590.

85. Act of Sept. 13, 1960, Pub. L. No. 86-770, § 3, 74 Stat. 912 (amending 46 U.S.C. § 742 (1958)). The other changes involved the rewording of existing sentences, such as substituting "owned or possessed" for "owned and possessed" and "any appropriate nonjury proceeding" for "at the time of the commencement of the action herein provided for, a hibel." Id.

86. See S. Rep. No. 1894, supra note 82, at 5, reprinted in [1960] U.S. Code Cong. \& AD. News 3585-86. The changes in the SIAA reflected the thoughts expressed in a lettcr that had been written to the Judiciary Committee by the Secretary of Commerce. The changes were to "go to the fundamentals" of the jurisdictional problem:

We beheve that the Suits in Admiralty Act (sec. 2 thereof) should be amended to clarify the jurisdiction of the district courts over suits arising under the Suits in Adiniralty Act to provide jurisdiction for proceedings in personam agamst the United States or corporations owned by the United States in respect of cases where a proceeding in adnuiralty could be inaintamed if a private person, vessel, cargo or other property was involved.

The present language in the first sentence of section 2 of. . . [the Suits in Admiralty

Act]... has given rise to judicial problens which involve questions of jurisdiction and

uncertainties as to the proper forum about which proponents of the bill coinplain.

Id. at 10, reprinted in [1960] U.S. CODE CONG. \& AD. News 3590-91.

The Senate report on the bill notes that the Senate intended the change in the SIAA to clarify the statute's confnsing language. See id. at 5 , reprinted in [1960] U.S. CODE CONG. \& AD. News 3586. The report cites several cases that deinonstrate the varied results of different interpretations of the words "cargo" and "merchant vessel." For example, in Ryan Stevedoring Co. v. Unitcd States, 175 F.2d 490 (2d Cir. 1949), the court decided that barrels of flammable inaterial awaiting loading onto a government ship were not "cargo" within the purview of the SIAA; hence, the government was not liable for any damage caused when the flammable material ignitcd, damaging adjacent ships. In Eastern S.S. Lines v. United States, 187 F.2d 956 (1st Cir. 1951), the court held that use of a chartered ship as a hospital ship was employment of the ship as a public vessel, not as a "merchant vessel," and thus the costs to the owner of reconverting the ship to inerchant use were not recoverable under the SIAA.

The SIAA has been amended once simce the 1960 amendments. Act of Aug. 29, 1972, Pub. L. No. $92-417, \S 3$, 86 Stat. 654 (amending 46 U.S.C. $\S 749$ (1970)). The purpose of the ainendment is to use the saine jurisdictional language of the 1960 amendments for the sections allowing the secretaries of the military departments to settle admiralty claims against the government through administrative processes. See S. REP. No. 1079, 92d Cong., 2d Sess. 1, reprinted in [1972] U.S. CODE CONG. \& AD. NEWs 3129,3129 . The legislative history of the 1972 change merely reiterates 
The primary impact of the changes in the SIAA has been to expand the Act's coverage from torts inflicted by or on a vessel to all maritime torts. ${ }^{87}$ The effect of this change is to place certain maritime tort claims that previously had been cognizable only under the FTCA within the purview of the SIAA. ${ }^{88}$

\section{Judicial Interpretation of the 1960 Amendments to the SIAA.}

The Supreme Court has narrowly interpreted the effect of the 1960 amendments on the SIAA and the PVA. In United States $v$. United Continental Tuna Corp. ${ }^{89}$ the Court refused to interpret the 1960 amendments as making the SIAA coextensive with the PVA. A Philippime corporation, seeking damages for a fishing boat that was sunk in a collision with a United States warship, brought suit under both the SIAA and the PVA. The district court held that the case was governed by the PVA because a warship had caused the damage. .0 Under the PVA, a foreign national cannot bring suit unless his government has waived its immunity from similar suits by United States citizens. ${ }^{91} \mathrm{Be}-$ cause this condition was not satisfied, the district court dismissed the case. ${ }^{92}$ The claimant appealed, contending that the SIAA, its scope broadened by the 1960 amendinents, now also covered cases involving public vessels. Although the appellate court accepted this argument, ${ }^{93}$ the Supreme Court, after reviewing the legislative history of the SIAA

that of the 1960 amendments: the change includes the "private person or property" language to clarify the confusion surrounding the law defining the jurisdiction of the district courts. Id. at 5 , reprinted in [1972] U.S. CODE CONG. \& AD. NEws 3133-34. Statements that the legislature nakes after a law has been enacted are not, of course, determinative of congresional intent. See Richmond Marine Panama, S.A. v. United States, 350 F. Supp. 1210, 1220 (S.D.N.Y. 1972), cited with approval in Roberts v. United States, 498 F.2d 520, 526 (9th Cir. 1974). But in referring to the 1960 amendments in the legislative history of the 1972 amendinents, Congress focused on the amendments' solution of jurisdictional problems, not on their substantive changes to the United States' liability for maritime torts.

87. For a succinct discussion of current admiralty law and of interpretations of maritime torts, see National Union Fire Ins. Co. v. United States, 436 F. Supp. 1078, 1080-82 (M.D. Tenn. 1977); Conner, Maritime Tort Liability of the United States, 11 J. MAR. L. \& CoM. 271 (1980).

88. See United States v. United Continental Tuna Corp., 425 U.S. 164, 176 n.14 (1976); Kelly v. United States, 531 F.2d 1144, 1149 (2d Cir. 1976); Roberts v. United States, 498 F.2d 520, 52526 (9th Cir.), cert. denied, 419 U.S. 1070 (1974); Brown v. United States, 403 F. Supp. 472,474 (C.D. Cal. 1975). But see McCormick v. United States, 645 F.2d 299 (5th Cir. 1981); Teich v. Umited States, 500 F. Supp. 891 (N.D. Ill. 1980) (finding the Coast Guard negligent in the placement of navigation aids under the FTCA without discussion of the applicability of the SIAA).

89. 425 U.S. 164 (1976).

90. Id. at 166 (district court case not reported).

91. 46 U.S.C. $\$ 785$ (1976).

92. See 425 U.S. at 166 (district court case not reported).

93. See United Continental Tuna Corp. v. United States, 499 F.2d 774, 777-78 (9th Cir. 1974), rev'd, 425 U.S. 164 (1976). The plaintiff corporation argued that the "any private person" language of the amendinent is so broad that it enables one to avoid the PVA and its restrictions 
and its 1960 amendments, concluded that the amendments were motivated by the "severe jurisdictional problems" attendant to filing a maritime claim. ${ }^{94}$ Notimg that it is "a cardimal principle of statutory construction that repeals by implication are not favored,"95 the Court rejected a broad imterpretation of the SIAA amendments that would have effectively stripped the jurisdictional provisions of the PVA of their vitality, and lield that the case liad been properly dismissed for failure to meet the PVA reciprocity provisions. ${ }^{96}$

The background of the SIAA mdicates that it was narrowly drawn to address two problems: the seizure of government vessels and the necessity of congressional disposition through private relief bills of maritime claims agamst the government. ${ }^{97}$ The 1960 amendments also were designed to respond to a discrete problem, that of jurisdictional confusion over the processing of admiralty claims. ${ }^{98}$ There is little question that the 1960 amendments effectively broadened the coverage of the SIAA to include maritime torts that previously could have been brought only under the FTCA.99 The history of the SIAA provides, however, no definitive answer to the question of whether a substantive change of immunity was intended to affect those claims that the SIAA had come to embrace. The indications are that no such change was contemplated. The rationale and the application of the discretionaryfunction exemption of the FTCA further supports this view.

\section{The Discretionary-Function Exemption of the FTCA.}

1. Legislative history. The FTCA's enactment in $1946^{100}$ reflected thirty years of attempts to enact a general waiver of the government's immunity for tort actions. ${ }^{101}$ The FTCA is not, lowever, an absolute waiver of sovereign immunity; it provides for specific exemptions to the waiver. ${ }^{102}$ The most important exemption is the "discretionary-func-

entirely, but does not preclude one from bringing suit under the PVA if its provisions are more favorable than those of the SIAA. See 499 F.2d at 778.

94. 425 U.S. at 172.

95. Id at 168 .

96. Id. at $\mathbf{1 8 1 .}$

97. See notes 44-45 supra and accompanying text.

98. See notes 84-86 supra and accoinpanying text.

99. See notes 87-88 supra and accoinpanying text.

100. See Legislative Reorganization Act of 1946, Pub. L. No. 79-601, tit. iv., 60 Stat. 812, 842 (codified im scattered sections of 28, 31, 33 U.S.C.).

101. See 2 L. JAYSON, supra note $11, \S \S 5,246$. For a discussion of the progressively broader waivers of government immunity prior to the enactment of the FTCA, see id. \$§ 52-55.

102. See 28 U.S.C. $\$ 2680$ (1976). 
tion" exemption, ${ }^{103}$ which provides that the waiver of immunity does not apply to

[a]ny claim based upon an act or omission of an employee of the Government . . . based upon the exercise or performance or the failure to exercise or perform a discretionary function or duty on the part of a federal agency or an employee of the Government, whether or not the discretion involved be abused. 104

The discretionary-function exemption limits the analogy in the FTCA between government liability and private liability. ${ }^{105}$ The generally accepted reason for this limitation is to restrict judicial review and supervision of policy decisions inade by the coordinate branches of government. ${ }^{106}$ The discretionary-function exemption, founded in the common law, ${ }^{107}$ evinces respect for the doctrine of separation of powers. ${ }^{108}$

The legislative history of the FTCA's discretionary-function exemption contains a straightforward description of the situations in which the exemption may apply. ${ }^{109} \mathrm{~A}$ more revealing and frequently cited $^{110}$ statement about the nature of the exemption was made by the Justice Department Assistant Attorney General in hearings before the House Judiciary Committee. ${ }^{111}$ In discussing the inclusion of the discretionary-function clause, he remarked: "It is not probable that the courts would extend a Tort Claims Act into the realin of the validity of legislation or discretionary administrative action, but [this bill] makes this specific." 112 Many courts, including the Supreine Court, ${ }^{113}$ have found this statement indicative of Congress's understanding of the exemption as a fundamental precept based on the separation of powers doctrine, that had been added only for clarity.

103. Id. $\$ 2680$ (a). See S. REP. No. 1196, 77th Cong., 2d Sess. 7 (1942) (describing this exemption as the "most important" one). The 1942 draft contains the same discretionary-function language that was finally enacted in the FTCA. See 2 L. JAYson, supra note 11, § 246.

104. 28 U.S.C. \$ 2680(a) (1976).

105. 2 L. JAYSON, supra note 11, § 245. See S. REP. No. 1196, supra note 103, at 7. The Senate report mentions several activities for which immunity was not waived, such as flood-control projects and regulatory decisions by the FTC or the SEC. Instead, the Act was intended to reach the common law torts of employees such as automobile collisions caused by negligence. $Y d$.

106. See $3 \mathrm{~K}$. Davis, supra note 11, § 25.13; L. JAFFe, Judicial ConTrol of ADMINISTRATIVE ACTION 259 (1965).

107. See 2 L. JAYSON, supra note 11 , $\$ 248.01$; Zillman, supra note 11 , at 16-30.

108. See notes $126-31$ infra and accompanying text.

109. See note 105 supra.

110. See, e.g., Laird v, Nelms, 406 U.S. 797, 801 (1972); Dalehite v. United States, 346 U.S. 15, 27 (1953); Canadian Transp. Co. v. United States, 1980 A.M.C. 2103, 2110 (D.C. Cir. 1980).

111. See Hearings on H.R. 5373 and 6463 Before the House Judiciary Comm. 77th Cong., 2d Sess. 29 (1942) (statement of Francis M. Shea).

112. Id.

113. See note 110 supra. 
2. Judicial development. Dalehite v. United States ${ }^{114}$ contains the Supreme Court's most extensive analysis of the FTCA's discretionaryfunction exeinption. Dalehite arose from a disastrous explosion in Texas City, Texas, im 1947 that killed 560 persons, injured over 3000 persons, demolished three ships in a port, and resulted in over one million dollars of property damage. ${ }^{115}$ The tragedy occurred when government-produced fertilizer that had been loaded aboard ships for export to war-torn European countries detonated. The district court held the government negligent in drafting and adopting the fertilizerexport plan, in manufacturing the fertilizer, and in failing to police adequately the loading of the fertilizer aboard the ships. ${ }^{116}$

The Supreme Court held that all of the government's allegedly negligent activities were immune under the discretionary-function exemption of the FTCA. ${ }^{117}$ The government's discretionary function, the Court reasoned, covers inore than the initiation of government programs and activities at the highest executive levels. In the Court's words, "[w]here there is room for policy judgment and decision there is discretion. It necessarily follows that acts of subordinates in carrying out the operations of government in accordance with official directions cannot be actionable." 118 The Court, in dicta, noted that the challenged government actions were "made at a planning rather than operational level" 119 and were properly within the protective einbrace of the exemption. ${ }^{20}$

Dalehite represents the furthest reach of the discretionary-function exemption, and although its facts may be unique, 121 the planning/operational dichotomy continues to be important in analyzing

114. 346 U.S. 15 (1953).

115. See id. at 48 (Jackson, J., dissenting).

116. 1950 A.M.C. 1084, 1084 (S.D. Tex. 1950), rev'd sub nom. In re Texas City Disaster Litigation, 197 F.2d 771 (5th Cir. 1952), affd sub nom. Dalehite v. United States, 346 U.S. 15 (1953).

117. 346 U.S. at $37-44$.

118. Id. at 36 .

119. Id. at 42 .

120. Justice Jackson, joined by two other Justices, dissented, contending that the discrctionary-function exemption had been interpreted too broadly. In essence, the dissenting Justices believed that the details of the fertilizer-export program had been carried out carelessly and that this lack of care was not covered by the discretionary-function exemption. The dissent noted that a broad reading of the discretionary-function exemption enasculates the FTCA. The old adage "The King can do no wrong" becomes "The King can do only little wrongs." Id. at 60 (Jackson, J., dissenting).

121. Several commentators have noted that the inass disaster nature of the imcident, its potential for huge financial liability, and concern over the decision's impact on the post-war foreign aid program inay have caused the Court to interpret the discretionary-function clause broadly. See Reynolds, supra note 11, at 97; Zillman, supra note 11, at 6-8. 
discretionary-function cases. ${ }^{122}$ The standard, however, has been criticized as imputing a test that is not justified by the words or the legislative history of the statute. ${ }^{123}$ An additional criticism is that such a standard merely shifts the controversy from defining "discretion" to identifying what is a planning-level decision and what is an operationlevel decision. ${ }^{124}$ Nevertheless, the standard is useful. Too broad an interpretation of discretion would allow the exception to swallow the rule, for every action by an einployee is to some degree discretionary. Too narrow an interpretation would subject all decisions of government to the possibility of an endless treadmill of hitigation. The planning/operational approach is sufficiently flexible to protect decisions of government that should be exempt from judicial review in accordance with the separation of powers doctrine, ${ }^{125}$ yet still to allow citizens to recover when wronged by neghigent government implementation of a pohicy.

\section{The Discretionary-Function Exemption AND the SIAA}

\section{A. Separation of Powers.}

Separation of powers is one of the cornerstone concepts of our constitutional system. Inherent in this constitutional framework is the accountability of the legislative and executive branches to the electorate. Elected representatives in the legislative and executive branches of government must make the sometimes difficult policy decisions regarding government programs and the allocation of resources. In addition, executive agencies must plan, decide on, and implement government pohicies. ${ }^{126}$ The executive branch, for example, loses some of its independence when its policy decisions are subject to judicial review or supervision. The apprehension of judicial scrutimy may inhibit the impleinentation of innovative approaches to problems, to the detriment of the public. 127

Courts are ill-equipped to balance the various concerus necessary in formulating governmental policy or to make decisions about the most efficient allocation of resources. The courtroom processes are bet-

122. See 2 L. JAYSON, supra note 11, § 249.07.

123. Id.

124. Id.

125. See generally 2 L. JAYSON, supra note $11, \S 249.07$.

126. Improper implementation of a predetermined policy does not, however, merit protection under the discretionary-function exemption.

127. Reynolds, supra note 11, at 121-22. See also Gregoire v. Biddle, 177 F.2d 579, 581 (2d Cir. 1949) (Judge Learned Hand, in discussing the need for immunity for federal officials, argued that the burden of lawsuits "would dampen the ardor of all but the most resolute, or the most irresponsible, in the unflinching discharge of their duties."). 
ter suited to the application of a principle to a given set of facts rather than to the forinulation of policy for major governmental undertakings that affect a multitude of people in a wide variety of situations across the country. Such decisions frequently require technical expertise in a variety of disciplines. The judiciary usually cannot consistently attam the desired depth of knowledge in any field because of the wide variety of cases that must be heard. ${ }^{128}$ In addition, the judiciary is further removed from the demands of the electorate than are the legislative and executive branches. ${ }^{129}$

Scarce man power and financial resources accentuate the judiciary's mability to make the best policy decisions. Because a court is constramed by the facts of the case before it, it may too easily render a decision without full appreciation of the consequences. An apparently just result in one case may have an adverse inpact on a larger scale. As the court noted in Magno v. Corros, ${ }^{130}$ in which the plamtiff boat owner asserted that the Coast Guard should have imstalled more lights along a dike, "[e]very dollar of [the Coast Guard's] money that we direct it to spend is diverted from another regulatory activity." 131 A court sinply does not have the depth of expertise and sufficient data before it to evaluate effectively all of the countervailing considerations. For example, consideration of the other regulatory functions that an agency must perform, may not be properly before a court when it applies a principle of law to the facts of the case. To avoid the danger that far-reaching policy decisions will be made by courts, discretionary-pohcy decisions should be immune from scrutimy in the courtroom.

\section{B. The Legislative History of the 1960 Amendments.}

The legislative history of the 1960 amendments reveals no congressional imtent to change the substantive hability of the United States for maritime torts. The Supreme Court recognized the limited purpose of the 1960 amendments-to resolve jurisdictional disputes-in United States v. United Continental Tuna Corp. ${ }^{132}$ The only possible basis to interpret the amendments as effectimg a substantive change in the waiver of immunity is to adopt the notion that all waivers of sovereign

128. See generally D. Horowitz, The Courts and Social Policy 1-67 (1977). Courts do, obviously, rely on information from different disciplines in trying and deciding cases. The difference, however, is in the scope of the task and the need for managerial talent to formulate governmental policy by effectively balancing speculation as to future developments, present priorities, and past experience.

129. See Reynolds, supra note 11, at 121-22.

130. 630 F.2d 224 (4th Cir. 1980), cert. denied, 451 U.S. 970 (1981).

131. Id. at 229.

132. 425 U.S. 164 (1976). See notes $89-96$ supra and accoinpanying text. 
immunity are to be given the broadest possible reading, as evidenced in the Lane v. United States ${ }^{133}$ and DeBardeleben Marine Corp. v. United States ${ }^{134}$ decisions. But there is no consistent view on this point in American jurisprudence; both narrow and broad constructions have appeared in cases. ${ }^{135}$ Both viewpoints rely strongly on glib phrases ${ }^{136}$ that are of little assistance in analyzing the problein. It is more helpful to analyze each question in light of basic policies such as the separation of powers doctrine and governmental goals as expressed by Congress. Historically, Congress has progressively expanded the government's waiver of immunity. ${ }^{137}$ Yet, Congress has been restrained in recognizing the government's liability for the acts of public officials exercismg their policynnaking judgment. ${ }^{138}$ Thus, the better approach is to assume there is immunity from liability for discretionary functions unless the statutory language explicitly provides otherwise.

Immunity-waiver statutes also should not be imterpreted inconsistently. ${ }^{139}$ Cases that have considered whether the SIAA contains a discretionary-function exemption have involved maritime tort actions that formerly could have been brought only under the FTCA, which clearly contains a discretionary-function exemption. It is anounalous for the jurisdictional modification contained in the 1960 amendments to effect a different outcome for suits formerly barred under the FTCA's discretionary-function exemption and now cognizable under the SIAA. ${ }^{140}$ Congress expressed no imtent to modify the treatment of such cases.

133. 529 F.2d 175 (4th Cir. 1975). For a discussion of this case, see notes 19-21 supra and accompanying text.

134. 451 F.2d 140 (5th Cir. 1971). For a discussion of this case, see notes 22-24 supra and accompanying text. See generally Comment, The Discretionary Function Exemptions and the Suits in Admiralty Act: A Safe Harbor for Negligence?, 4 U. PUGET Sound L. Rev. 385 (1981); 13 B.C. INDUS. \& COM. L. Rev. 1546, 1551 (1972).

135. Compare United States v. Yellow Cab Co., 340 U.S. 543, 550 (1951) (broad interpretation of waiver of immunity in the FTCA) and Gulf Oil Corp. v. Panama Canal Co., 407 F.2d 24, 28 (5th Cir. 1969) (broad reading of the FTCA) with United States v. Sherwood, 312 U.S. 584,590 (1941) (narrow construction of the Tucker Act) and Blanco v. United States, 464 F. Supp. 927, 931 (S.D.N.Y. 1979) (narrow reading of the SIAA/PVA).

136. See, e.g., DeBardeleben Marine Corp. v. United States, 451 F.2d 140, 146 (5th Cir. 1971) ("The tide of history is running clearly against the concept of sovereign immunity.").

137. See 1 L. JAYSON, supra note 11, \$§ 51-64.

138. See rotes 69-70, 102-05 supra and acconipanying text.

139. Sce United States v. United Continental Tuna Corp., 425 U.S. 164, 168-69 (1976); Laird v. Nelms, 406 U.S. 797, 802 (1972).

140. CF. Laird v. Nelms, 406 U.S. 797 (1972) (in an action under the FTCA for damages caused by a sonic boom, the government could not be held absolutely hable under a theory of engaging in inherently dangerous activities; nor could it be held hable under a trespass theory-to allow the trespass theory to succeed when the absolute liability argument had failed "would be to judicially admit at the back door that which has been turned away at the front door"). Id. at 802 . 


\section{CONCLUSION}

The reasoning of courts that have refused to recognize a discretionary-function exemption in the SIAA is simple: because the statute does not provide for a discretionary-function exemption, none exists. This analysis reflects an attitude that favors the broadest possible reading of any waiver of the government's sovereign immunity. This attitude is consonant with the historical progression away from sovereign immunity and toward greater liability of the government for its actions.

There are, llowever, further considerations. The first is recognition of the separation of powers doctrine. Courts that have recognized a discretionary-function exemption maintain that courts do not liave the inherent power to review the discretionary decisions of a coordinate branch of government, and they readily infer a discretionary-function exemption into the SIAA. The second consideration is the legislative history of the 1960 amendments to the SIAA. The legislative history indicates that Congress did not intend to alter the outcome of maritime tort claims previously cognizable under only the FTCA by reinoving the discretionary-function exemption to the waiver of immunity for such torts.

The appropriate course for the courts to follow is to imply the discretionary-function exemption into the SIAA. Implying this exemption offers the best balance between affording an imjured party the opportumity to recover for government negligence in the implementation of a program or policy and restricting the judiciary from impeding policies-or worse, making its own policies-that are properly the responsibility of coordmate branclies of government. 